\title{
Genetic structure in the nonrewarding, bumblebee-pollinated orchid Calypso bulbosa
}

\author{
RONNY ALEXANDERSSON* \& JON ÅGREN $\dagger$ \\ Ecological Botany, Department of Ecology and Environmental Science, Umeå University, SE-901 87 Umeå, Sweden
}

\begin{abstract}
Among- and within-population variation at neutral loci is governed by an interaction between stochastic processes and gene flow. A previous study of pollen dispersal in which the transfer of individually marked pollinia was monitored, indicated not only that populations of the nonrewarding, bumblebee-pollinated orchid Calypso bulbosa are connected by substantial levels of gene flow, but also that seed production may be the result of self-fertilization to a considerable extent. We examined the genetic structure of 21 C. bulbosa populations in northern Sweden by $F$-statistics analyses of variation at three polymorphic allozyme loci. Four populations each consisted of two or three distinct patches, which also allowed us to evaluate among-patch differentiation. The inbreeding coefficient over all loci within populations was high $\left(F_{\mathrm{IS}}=0.283\right) . F$-statistics indicated that the level of genetic differentiation among patches within populations varied among populations. $F_{\mathrm{ST}}$ among patches within populations ranged between -0.021 and 0.119 and was significantly different from zero in two of the populations. There was low to moderate genetic differentiation among populations $\left(F_{\mathrm{ST}}=0.072\right)$. A Mantel test indicated a positive correlation between geographical and genetic distances among populations, but this correlation was dependent on the difference in allele frequencies between the southernmost population sampled and all other populations. Self-fertilization and substructuring within sampling units (within patches and populations) may have contributed to the high inbreeding coefficients observed in many C. bulbosa populations. Long-distance seed and pollen dispersal may account for the low to moderate genetic differentiation among populations.
\end{abstract}

Keywords: deceptive pollination, $F$-statistics, Orchidaceae, population differentiation.

\section{Introduction}

The mating system and the dispersal characteristics of pollen and seeds will influence the genetic structure of natural plant populations (e.g. Hamrick \& Godt, 1989; Williams \& Gurie, 1994; Giles et al., 1998). In highly selfing species with limited seed and pollen dispersal, inbreeding coefficients are expected to be high, and most of the genetic variation at neutral loci is expected to be observed among populations. In contrast, outcrossing species with wide seed and pollen dispersal are expected to be characterized by low inbreeding coefficients and by limited population differentiation at neutral loci.

The geographical structure of genetic variation at neutral loci should depend on patterns of gene flow. If gene dispersal is limited and founders of new popula-

\footnotetext{
*Correspondence. E-mail: ronny.alexandersson@eg.umu.se $\dagger$ Present address: Department of Plant Ecology, EBC, Uppsala University, Villavägen 14, SE-752 36 Uppsala, Sweden
}

tions are more likely to originate from neighbouring than from distant populations (the stepping-stone model), this may contribute to a correlation between geographical and genetic distance (Kimura \& Weiss, 1964; Slatkin, 1985). If, on the other hand, founders are drawn at random from populations over a large geographical area (the island model), then this should reduce any correlation between geographical and genetic distance (Wright, 1951; Slatkin, 1985).

In this study, we used allozyme variation and $F$-statistics (Wright, 1951) to document the genetic structure in the bumblebee-pollinated, nonrewarding orchid Calypso bulbosa. A previous study of pollen dispersal in two Swedish C. bulbosa populations where pollinia were marked individually showed: (i) that the rate of self-pollination was considerable $(18-37 \%$ of pollinated flowers); (ii) that the pollen dispersal distances within populations were distributed leptokurtically (median dispersal distances to the seventh-closest flowering plant); and, finally (iii) that a substantial 
fraction of the pollen deposited originated from plants outside the study patches (5-14\% of pollinated flowers; J. Ågren, R. Alexandersson \& A.R. Waites, unpubl. $\mathrm{mss}$ ). From these observations, we can formulate several predictions concerning the structure of genetic variation at neutral loci in C. bulbosa. First, the high rate of selfpollination should result in relatively high fixation indices within populations $\left(F_{\text {IS }}\right)$. Secondly, the relatively long dispersal distances of pollen within populations and the considerable pollen flow among populations should be associated with low levels of genetic differentiation among populations and among patches within populations $\left(F_{\mathrm{ST}}\right)$. To examine these predictions, we quantified the fixation indices and the level of amongpopulation differentiation for 21 populations of C. bulbosa in northern Sweden. To assess withinpopulation differentiation, we quantified among-patch differentiation in four populations consisting of two or three distinct patches separated by $50-90 \mathrm{~m}$. Finally, we used the Mantel test to quantify the correlation between geographical and genetic distances among C. bulbosa populations.

\section{Materials and methods}

\section{Study species}

Calypso bulbosa L. (Orchidaceae) is a diploid $(2 n=24$; Lid, 1979), self-compatible, nonautogamous, perennial herb (Ackerman, 1981). Calypso bulbosa has a circumboreal distribution and the species is divided into four varieties (Hultén \& Fries, 1986). The variety Calypso bulbosa bulbosa is found in the northern parts of Sweden, Finland and Russia (Hultén \& Fries, 1986). In Sweden, it grows in relatively nutrient-rich, mesic to moist spruce (Picea abies (L.) Karst.) and spruce-pine (P. abies - Pinus sylvestris L.) forests.

The plant forms a single leaf from an underground corm in late summer. In spring, reproductive plants develop a $4-15 \mathrm{~cm}$ tall inflorescence with a single flower with pink petals and sepals. In northern Sweden, C. bulbosa flowers for 3-4 weeks beginning in late May or early June. The flowers are nonrewarding (i.e. do not offer a reward to flower visitors) and are pollinated by bumblebee queens (Alexandersson \& Ågren, 1996; J. Ågren, R. Alexandersson \& A.R. Waites, unpubl. mss). The fruit matures in late July and may contain thousands of small seeds [mean length of seeds ( $\pm \mathrm{SD}$ ): $0.74 \pm 0.17 \mathrm{~mm}, N=10]$. The old leaf senesces during fruit development. In August, the plant forms one, or sometimes two new corms. In five populations in northern Sweden, an average of $12 \%$ of the adult plants had more than one corm (range 9-21\%; R. Alexandersson \& J. Ågren, unpubl. data).

\section{Allozyme electrophoresis}

The study was carried out in 21 populations in the counties of Västerbotten and Norrbotten in northern Sweden. The latitude of the study populations ranged from $63^{\circ} 53^{\prime} \mathrm{N}$ to $65^{\circ} 44^{\prime} \mathrm{N}$ and their altitude from $75 \mathrm{~m}$ to $430 \mathrm{~m}$ a.s.l. (Fig. 1, Table 1). A population was defined as a group of plants separated from the nearest conspecific by at least $100 \mathrm{~m}$. Population size was quantified as the mean number of flowering plants 1992-94 and ranged between 19 and 667 (Table 1). Four study populations were subdivided into distinct patches, separated by $50-90 \mathrm{~m}$, each including about $30-70$ flowering plants. Population 1 was divided into three patches and populations 2, 17 and 20 into two patches each (Fig. 1, Table 1).

In each population (or patch; populations 1, 2, 17 and 20 ), we collected the tip of a leaf from 30 to 90 randomly chosen adult plants. In order to avoid sampling the same genet more than once, sampled plants were always separated by at least $1 \mathrm{~m}$.

The sampled leaf tips were transported to the laboratory in Eppendorf tubes that were filled with water and stored on ice. Within $28 \mathrm{~h}$ of sampling, the samples were homogenized with a Tris- $\mathrm{HCl}$ extraction buffer (Peakall \& Beattie, 1991) and a small amount of sand. Enzyme extracts were absorbed onto wicks and frozen at $-70^{\circ} \mathrm{C}$. Within 3 months, electrophoresis was performed on horizontal starch gels. The electrophoresis was run at $250 \mathrm{~V}$ and $50 \mathrm{~mA}$ for $6 \mathrm{~h}$. We used Ashtonbuffers as gel $(\mathrm{pH} 8.2)$ and electrode buffers $(\mathrm{pH} 8.4$; described in Soltis et al., 1983). Stain receipes were modified from Wendel \& Weeden (1989), and interpretable bands were obtained for three enzyme systems: aspartate aminotransferase (Aat; EC 2.6.1.1), triosephosphate isomerase (Tpi; EC 5.3.1.1) and phosphoglucomutase (Pgm; EC 5.4.2.2).

\section{Statistical analysis}

We used $\chi^{2}$-tests in order to determine whether there was variation in allele frequencies among populations. In population 7, three alleles were detected at the Pgm locus; in this case, the two rare alleles were pooled before testing.

We used $F$-statistics (Wright, 1951) to characterize the genetic structure within and among populations. The $F$-statistics were calculated using the Weir \& Cockerham (1984) estimators and the program FSTAT v1.2 (Goudet, 1995). Standard errors were estimated by jack-knifing, and confidence intervals by boot-strapping. The hierarchical levels in the data were denoted in the conventional way: $F_{\mathrm{IS}}, F_{\mathrm{ST}}$ and $F_{\mathrm{IT}}$, where $\mathrm{I}=$ individual, $\mathrm{S}=$ population and $\mathrm{T}=$ total. In order to quantify genetic 
(a)
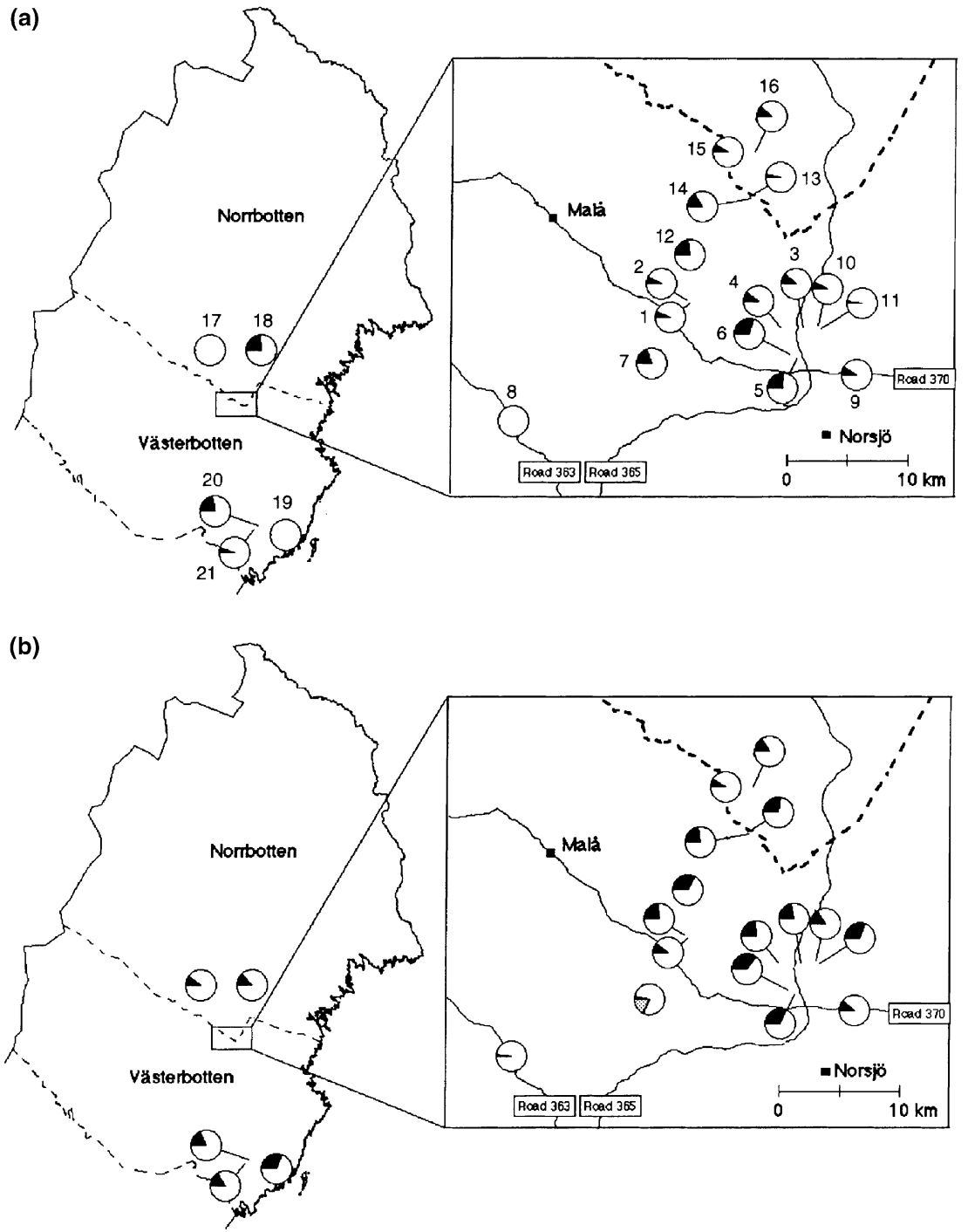

Fig. 1 Allele frequencies at three allozyme loci, in 21 Calypso bulbosa populations sampled in the provinces of Västerbotten and Norrbotten in northern Sweden: (a) Aat, (b) Pgm and (c) Tpi. Population numbers (see Table 1) are given in (a).

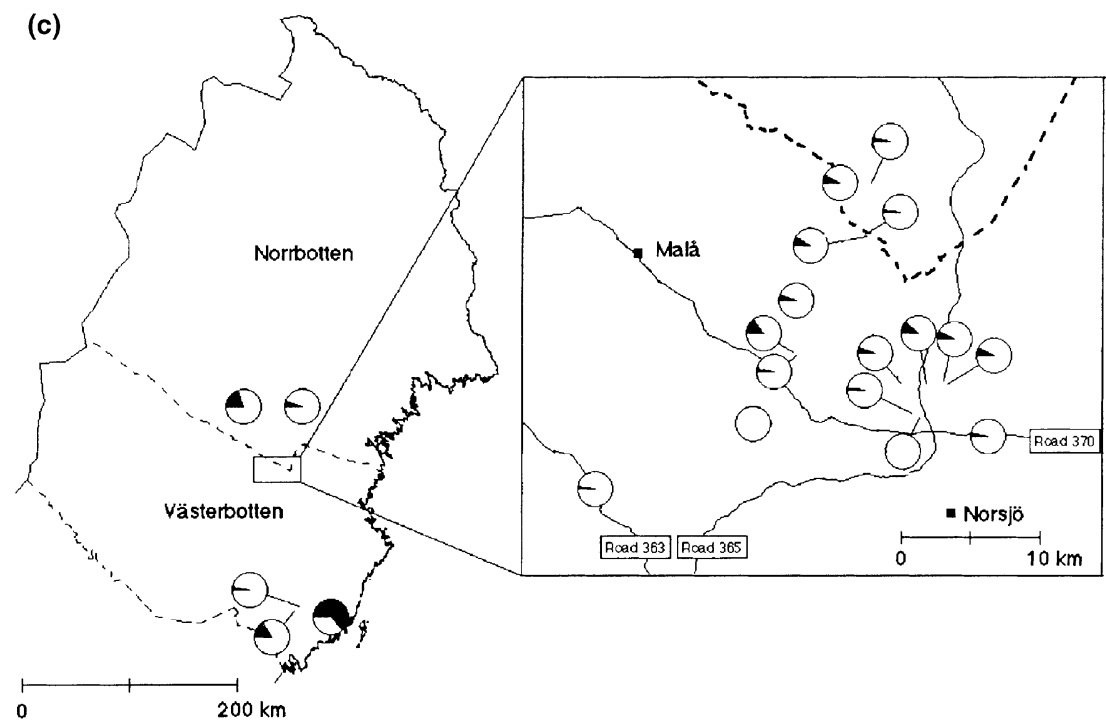

(C) The Genetical Society of Great Britain, Heredity, 85, 401-409. 
Table 1 Size (mean number of flowering plants 1992-94), altitude, inbreeding coefficient within population ( $F_{\text {IS }}$ ), sample size $(N)$ and heterozygosity (observed and expected) of 21 Calypso bulbosa populations in northern Sweden (see Fig. 1 for location of populations)

\begin{tabular}{lrcccccc}
\hline & & & & & \multicolumn{2}{c}{ Heterozygosity observed (expected) } \\
\cline { 6 - 7 } Population & Size & Altitude $(\mathrm{m})$ & $F_{\text {IS }}$ & $N$ & $T p i$ & Pgm & Aat \\
\hline 1 Kron-Olle 1 & 156 & 280 & 0.226 & 90 & $0.26(0.24)$ & $0.21(0.36)$ & $0.10(0.14)$ \\
2 Kron-Olle 2 & 137 & 280 & 0.439 & 60 & $0.05(0.05)$ & $0.03(0.18)$ & $0.12(0.12)$ \\
3 Finnliden farm & 48 & 280 & 0.032 & 30 & $0.23(0.21)$ & $0.25(0.34)$ & $0.23(0.21)$ \\
4 Ol-ersa & 159 & 235 & 0.431 & 30 & $0.10(0.10)$ & $0.14(0.37)$ & $0.13(0.18)$ \\
5 Borup 1 & 150 & 280 & 0.606 & 30 & $0.00(0.00)$ & $0.15(0.43)$ & $0.17(0.39)$ \\
6 Borup 2 & 61 & 305 & 0.144 & 30 & $0.03(0.03)$ & $0.28(0.46)$ & $0.50(0.42)$ \\
7 V. Högkulla & 263 & 350 & 0.516 & 30 & $0.00(0.00)$ & $0.07(0.07)$ & $0.27(0.33)$ \\
8 Kittelforsheden & 86 & 250 & 0.000 & 30 & $0.03(0.03)$ & $0.03(0.03)$ & $0.00(0.00)$ \\
9 Kryddgrovan & 19 & 225 & 0.229 & 30 & $0.07(0.07)$ & $0.17(0.21)$ & $0.10(0.16)$ \\
10 Finnliden 1 & 284 & 280 & 0.146 & 30 & $0.13(0.13)$ & $0.19(0.29)$ & $0.13(0.13)$ \\
11 Finnliden 2 & 44 & 280 & 0.379 & 30 & $0.13(0.13)$ & $0.20(0.43)$ & $0.03(0.03)$ \\
12 Näsberg & 146 & 290 & 0.402 & 30 & $0.10(0.10)$ & $0.04(0.44)$ & $0.39(0.36)$ \\
13 Järvselet 1 & 20 & 285 & 0.011 & 30 & $0.03(0.03)$ & $0.39(0.40)$ & $0.07(0.07)$ \\
14 Järvselet 2 & 36 & 290 & 0.162 & 30 & $0.17(0.16)$ & $0.32(0.36)$ & $0.17(0.26)$ \\
15 Sandfors & 48 & 300 & 0.239 & 30 & $0.07(0.13)$ & $0.11(0.17)$ & $0.17(0.16)$ \\
16 Lidmyrliden & 158 & 335 & 0.002 & 30 & $0.07(0.07)$ & $0.23(0.26)$ & $0.23(0.21)$ \\
17 Döttern & 96 & 430 & 0.101 & 59 & $0.32(0.32)$ & $0.12(0.18)$ & $0.00(0.00)$ \\
18 Vistån & 667 & 285 & 0.405 & 30 & $0.03(0.10)$ & $0.13(0.24)$ & $0.26(0.37)$ \\
19 Ersmarksberget & 49 & 75 & 0.144 & 30 & $0.47(0.47)$ & $0.30(0.43)$ & $0.00(0.00)$ \\
20 Orrböle & 72 & 175 & 0.147 & 60 & $0.05(0.05)$ & $0.19(0.30)$ & $0.37(0.35)$ \\
21 Fällfors & 107 & 155 & 0.089 & 30 & $0.23(0.26)$ & $0.24(0.27)$ & $0.10(0.10)$ \\
\hline
\end{tabular}

differentiation among patches within populations 1,2, 17 and 20, we calculated $F$-statistics separately for each population. A 'P' was added to the conventional subscripts $\left(F_{\mathrm{IS}(\mathrm{P})}, F_{\mathrm{ST}(\mathrm{P})}\right.$ and $\left.F_{\mathrm{IT}(\mathrm{P})}\right)$ in this analysis to avoid confusion with the previous analysis. To test for neutrality among loci, we examined whether the confidence intervals of $F_{\text {IS }}$ over populations overlapped or lay between the confidence intervals of $F_{\text {IS }}$ over loci (Goudet et al., 1995).

A Mantel test (Manly, 1985) was performed to determine whether there was a correlation between geographical and genetic distances among populations.

\section{Results}

The over-population confidence intervals of $F_{\text {IS }}$ for each locus overlapped or lay between the over-loci confidence intervals (data not shown) and therefore all three loci were assumed neutral and included in the analysis.

Two alleles were detected at the Tpi and Aat loci, and three alleles at the Pgm locus. One of the Pgm-alleles was found in only one population (Population 7; Fig. 1). Allele frequencies differed significantly among populations (d.f. $=20 ;$ Tpi: $\chi^{2}=173 ;$ Pgm: $\chi^{2}=66 ;$ Aat: $\left.\chi^{2}=128 ; P<0.0001\right)$. Five populations were monomorphic for one allozyme locus (two populations lacked variation at the Tpi locus, and three populations lacked variation at the Aat locus; Fig. 1). No population was monomorphic for more than one locus (Fig. 1). In most populations, the expected heterozygosity was highest for $\operatorname{Pgm}$ (Table 1), indicating that this was the most informative locus.

$F_{\text {IS }}$ was positive at all three loci, indicating a deficiency of heterozygotes within populations, and the overall estimate was significantly greater than zero $\left(F_{\text {IS }}=0.283\right.$; Table 2$)$. The among-locus variation in estimates of $F_{\text {IS }}$ was large (range 0.008-0.429; Table 2). Estimates of $F_{\mathrm{IS}}$ for individual populations tended to be positively correlated with population size $(r=0.39$, $P=0.08, N=21$; Table 1).

The magnitude of genetic differentiation among patches within populations varied $\left(F_{\mathrm{ST}(\mathrm{P})}\right.$; Table 3$)$. The estimates of patch differentiation within populations based on three loci ranged from -0.021 to 0.119 , and were statistically different from zero in populations 1 and 2 (Table 3). $F_{\mathrm{IS}(\mathrm{P})}$ was higher than $F_{\mathrm{ST}(\mathrm{P})}$ in all four populations (Table 3 ).

Population divergence measured by $F_{\mathrm{ST}}$ was low to moderate (Table 2). Population 19 had a strong influence on $F_{\mathrm{ST}}$, because of its strongly deviating allele frequencies at the Tpi locus (Fig. 1). If population 19 is excluded from the calculation of $F$-statistics, the 
Table $2 F_{\mathrm{IS}}, F_{\mathrm{ST}}$ and $F_{\mathrm{IT}}( \pm \mathrm{SE})$ estimated for all 21 Calypso bulbosa populations sampled, and for a data set from which population 19, which had strongly deviating allele frequencies at the Tpi-locus (see Fig. 1), was excluded. Standard errors were estimated by jackknifing and confidence intervals $(\mathrm{CI})$ by bootstrapping

\begin{tabular}{|c|c|c|c|c|c|c|}
\hline \multirow[b]{2}{*}{ Source } & \multicolumn{3}{|c|}{$F$-statistics based on 21 populations } & \multicolumn{3}{|c|}{$F$-statistics based on 20 populations } \\
\hline & $F_{\text {IS }}$ & $F_{\mathrm{ST}}$ & $F_{\mathrm{IT}}$ & $F_{\text {IS }}$ & $F_{\mathrm{ST}}$ & $F_{\text {IT }}$ \\
\hline$T p i$ & $0.008 \pm 0.033$ & $0.201 \pm 0.141$ & $0.208 \pm 0.145$ & $0.007 \pm 0.039$ & $0.045 \pm 0.016$ & $0.052 \pm 0.037$ \\
\hline Pgm & $0.429 \pm 0.053$ & $0.034 \pm 0.013$ & $0.449 \pm 0.055$ & $0.436 \pm 0.056$ & $0.034 \pm 0.013$ & $0.456 \pm 0.057$ \\
\hline Aat & $0.110 \pm 0.066$ & $0.068 \pm 0.018$ & $0.170 \pm 0.062$ & $0.109 \pm 0.066$ & $0.063 \pm 0.017$ & $0.166 \pm 0.062$ \\
\hline Total & $0.283 \pm 0.159$ & $0.072 \pm 0.042$ & $0.329 \pm 0.115$ & $0.289 \pm 0.161$ & $0.044 \pm 0.011$ & $0.319 \pm 0.146$ \\
\hline $95 \%$ CI & $0.012-0.429$ & $0.035-0.180$ & $0.170-0.449$ & $0.012-0.435$ & $0.035-0.064$ & $0.054-0.455$ \\
\hline
\end{tabular}

Table 3 Separate $F$-statistics for four populations of Calypso bulbosa subdivided into distinct patches: KronOlle 1 (three patches), Kron-Olle 2, Döttern and Orrböle (two patches each). Standard errors of total estimates were calculated by jack-knifing. Estimates significantly different from zero $(P<0.05)$ are indicated in boldface

\begin{tabular}{lccccr}
\hline Population & Level & \multicolumn{1}{c}{$T p i$} & $P g m$ & \multicolumn{1}{c}{ Aat } & Total $( \pm$ SE) \\
\hline Kron-Olle 1 & $F_{\mathrm{IS}(\mathrm{P})}$ & -0.052 & $\mathbf{0 . 4 2 2}$ & $\mathbf{0 . 2 7 1}$ & $\mathbf{0 . 2 3 8}(0.168)$ \\
& $F_{\mathrm{ST}(\mathrm{P})}$ & -0.013 & $\mathbf{0 . 0 8 3}$ & -0.010 & $\mathbf{0 . 0 3 5}(0.036)$ \\
& $F_{\mathrm{IT}(\mathrm{P})}$ & -0.066 & $\mathbf{0 . 4 8 2}$ & $\mathbf{0 . 2 6 3}$ & $\mathbf{0 . 2 7 0}(0.192)$ \\
Kron-Olle 2 & $F_{\mathrm{IS}(\mathrm{P})}$ & -0.036 & $\mathbf{0 . 7 9 8}$ & -0.046 & $\mathbf{0 . 4 5 5}(0.392)$ \\
& $F_{\mathrm{ST}(\mathrm{P})}$ & $\mathbf{0 . 0 3 4}$ & $\mathbf{0 . 1 7 5}$ & -0.017 & $\mathbf{0 . 1 1 9}(0.089)$ \\
& $F_{\mathrm{IT}(\mathrm{P})}$ & 0.000 & $\mathbf{0 . 8 3 3}$ & -0.064 & $\mathbf{0 . 5 5 7}(0.431)$ \\
Döttern & $F_{\mathrm{IS}(\mathrm{P})}$ & -0.009 & $\mathbf{0 . 3 2 7}$ & $\mathrm{m}$ & $0.041(0.197)$ \\
& $F_{\mathrm{ST}(\mathrm{P})}$ & -0.017 & 0.050 & $\mathrm{~m}$ & $-0.004(0.039)$ \\
& $F_{\mathrm{IT}(\mathrm{P})}$ & -0.026 & $\mathbf{0 . 3 6 1}$ & $\mathrm{m}$ & $0.046(0.226)$ \\
Orrböle & $F_{\mathrm{IS}(\mathrm{P})}$ & -0.012 & $\mathbf{0 . 3 7 3}$ & -0.035 & $0.134(0.203)$ \\
& $F_{\mathrm{ST}(\mathrm{P})}$ & -0.011 & -0.024 & -0.019 & $-0.021(0.003)$ \\
& $F_{\mathrm{IT}(\mathrm{P})}$ & -0.023 & $\mathbf{0 . 3 5 8}$ & -0.055 & $0.116(0.205)$ \\
\hline
\end{tabular}

$\mathrm{m}$, monomorphic locus. single-locus $T p i$-estimate of $F_{\mathrm{ST}}$ is reduced from 0.201 to 0.045 and $F_{\mathrm{ST}}$ over all loci is reduced from 0.072 to 0.044 (Table 2). The estimates of other $F$-statistics were affected only marginally by the exclusion of population 19 (Table 2).

There was a positive correlation between genetic distance and geographical distance among populations (Mantel test: $r=0.40, P<0.05, N=210$; Fig. 2), but this correlation was totally dependent on the difference in allele frequencies between population 19 (which was the southernmost population sampled) and the other populations. If population 19 is excluded, there is no significant correlation between genetic and geographical distances among populations $(r=0.05, \quad P>0.05$, $N=190$; Fig. 2).

\section{Discussion}

This study has documented a high fixation index within populations $\left(F_{\text {IS }}\right)$ and a low to moderate level of genetic differentiation among populations of the nonrewarding orchid Calypso bulbosa. In two of the four populations investigated, there was significant genetic differentiation among patches within populations.

Both inbreeding and genetic substructuring within sampling units may contribute to the high $F_{\text {IS }}$ values. In order to produce the observed fixation indices, selfing rates in the order of $34 \% \pm 5 \%$ (mean $\pm \mathrm{SE}, N=21$ ) would be required [based on the formula $s=2 F /(1+F)$, where $s$ is the selfing rate, and $F$ is the within-population fixation index; Jain, 1979]. Interestingly, these values correspond well with data on pollen transfer in populations 1 and 2. In a three-year study of these populations, where individual pollinia were marked with microtags, $18-37 \%$ of the pollinated flowers were pollinated with self-pollen (J. Agren, R. Alexandersson \& A.R. Waites, unpubl. mss). This suggests that the high fixation indices can be explained to a large extent by self-fertilization, provided that inbreeding depression is low. In C. bulbosa, there is no significant difference in fruit set after self-and cross-pollination (R. Alexandersson, unpubl. data). However, there is no information on whether the probability of establishment differs between offspring produced after selfing and outcrossing, 


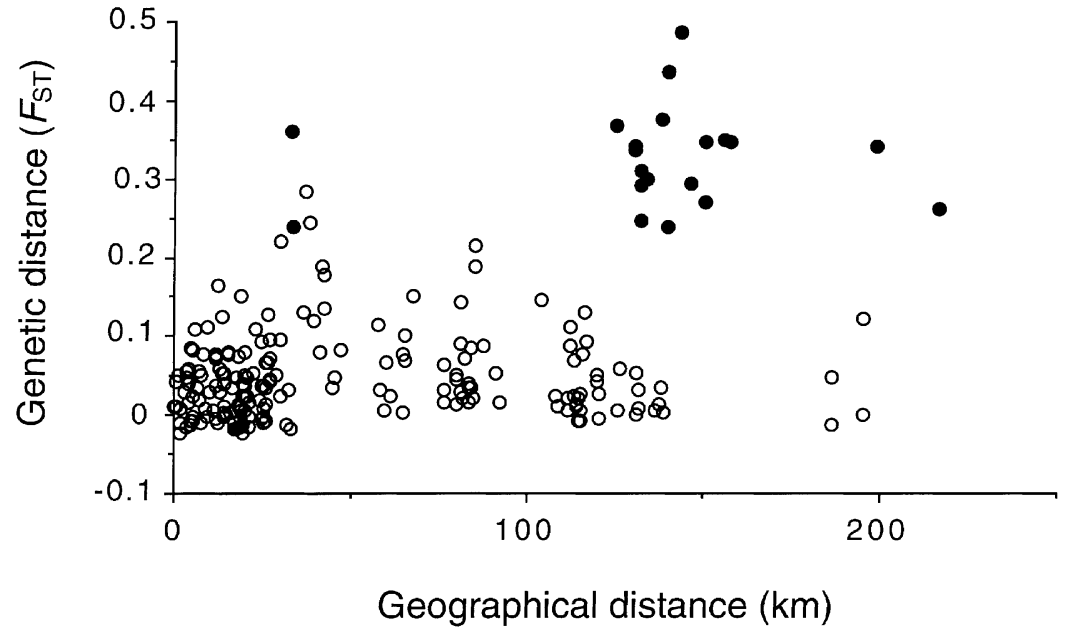

Fig. 2 Relationship between geographical and genetic distances (pairwise $F_{\mathrm{ST}}$ ) among 21 Calypso bulbosa populations in northern Sweden. Filled circles represent pairwise distances from population 19 (see Fig. 1, Table 1). respectively. Pollinators mediate any self-pollination in C. bulbosa, as this species does not have a mechanism for autogamy (Ackerman, 1981; R. Alexandersson, pers. obs.). Moreover, cage experiments indicate that a fair proportion of bumblebee visits may result in the deposition of self-pollen (J. Ågren, R. Alexandersson \& A.R. Waites, unpubl. mss).

In this study, plants were sampled throughout the investigated populations. Because large populations should be more likely to be differentiated into subpopulations, the tendency for $F_{\text {IS }}$ to be correlated positively with population size $(r=0.39, P=0.08)$ suggests that limited pollen and seed dispersal within sampling units may contribute to the high estimates of $F_{\mathrm{IS}}$, at least in large populations.

Limited pollen dispersal seems to be a less likely reason for the deficiency of heterozygotes within patches, however. The neighbourhood area based on pollen dispersal $\left(N_{\mathrm{A}}\right)$ can be estimated using the formula $N_{\mathrm{A}}=0.25 \pi k \sigma^{2}$, where $\sigma^{2}$ is the variance in absolute pollen dispersal and $k$ is a correction for kurtosis (Crawford, 1984; Fenster, 1991). Using data on withinpatch pollen dispersal collected in populations 1 and 2 (J. Ågren, R. Alexandersson \& A.R. Waites, unpubl. mss), the neighbourhood area was estimated as $130 \mathrm{~m}^{2}$ $\left(\sigma^{2}=184 \mathrm{~m}\right.$, leptokurtosis $\left.\gamma_{2}=10.4, k=0.9\right)$. This corresponds roughly to the overall sizes of the patches in populations 1 and 2 , and suggests that limited dispersal of pollen leaving the paternal plant may contribute to high estimates of $F_{\text {IS }}$ in large populations, but is unlikely to contribute to substructuring within patches.

Limited seed dispersal may contribute to the deficiency of heterozygotes within populations of C. bulbosa. Orchid seeds are generally assumed to be dispersed widely because of their small size (Murren \& Ellison, 1998). Although the seeds of C. bulbosa are similar in size to those of many other terrestrial orchids (cf. Rasmussen, 1995, p. 8), seed dispersal in C. bulbosa could be more restricted than in many other orchids, because the fruit stalk is short $(10-15 \mathrm{~cm})$ and because wind speeds should be reduced significantly close to the ground in the typical forest habitats of $C$. bulbosa. Field observations indicate that $C$. bulbosa seeds are commonly deposited close to the maternal plant (R. Alexandersson, pers. obs.).

The documented substructuring within sampling units is not likely to be caused by vegetative propagation and sampling within clones. Although individual C. bulbosa can produce two corms under favourable conditions, different shoots belonging to the same genet will be closely clumped, and care was taken in the present study not to sample more than one shoot from clumps of shoots that could have arisen through vegetative propagation.

There are few published estimates of fixation indices in orchid populations. Peakall \& Beattie (1996) documented high $F_{\text {IS }}(0.275)$ in populations of the wasp-pollinated, sexually deceptive, orchid Caladenia tentactulata. A spatial autocorrelation analysis indicated that their study populations consisted of breeding units with a diameter of 2-7 m. Because the mean pollen dispersal distance was about $15 \mathrm{~m}$, the authors suggested that the high inbreeding coefficients in C. tentactulata were caused by limited seed dispersal. In contrast, Peakall \& James (1989) estimated $F_{\text {IS }}$ as -0.015 (not significantly different from zero) in the clonal, rewarding, ant-pollinated orchid Leporella fimbriata. In this species, the low $F_{\text {IS }}$ was surprising, as $70 \%$ of documented pollinator movements were within clones. The authors suggested that efficient seed dispersal and inbreeding depression could explain the low fixation index.

The level of population differentiation observed in C. bulbosa $\left(F_{\mathrm{ST}}=0.072, N=21\right)$ is lower than the 
average level documented for plant species with winddispersed seeds (mean $\pm \mathrm{SE}, \quad G_{\mathrm{ST}}=0.14 \pm 0.02$, $N=121)$ and for animal-pollinated plants with mixedmating systems $\left(G_{\mathrm{ST}}=0.22 \pm 0.02, N=60\right.$; Hamrick $\&$ Godt, 1989). The low to moderate level of population differentiation in C. bulbosa is consistent with data collected for several other orchids (e.g. Scacchi et al., 1990; Rossi et al., 1992; Arft \& Ranker, 1998), and may reflect efficient gene dispersal among orchid populations. In C. bulbosa, a substantial inflow of pollen from outside the local patch has been documented (J. Agren, R. Alexandersson \& A.R. Waites, unpubl. mss), whereas in other orchids an efficient seed dispersal has been implicated (e.g. Corrias et al., 1991; Rossi et al., 1992).

In animal-pollinated plants, patterns of reward production affect pollinator behaviour, and may therefore be expected to influence pollen dispersal distances and population structure. Reward-producing animalpollinated plants are often characterized by a high proportion of near-neighbour matings (e.g. Levin \& Kerster, 1974; Fenster, 1991), which may restrict pollen dispersal distances and increase genetic differentiation among patches/populations (Turner et al., 1982). In nonrewarding plants, nearest-neighbour matings should be less frequent and pollen dispersal distances longer than in rewarding species (Peakall \& Beattie, 1996; J. Ågren, R. Alexandersson and A. R. Waites, unpubl. mss). As a result, the level of genetic differentiation among populations, and among patches within populations, should be lower in nonrewarding than in reward-producing plants. In order to test this hypothesis, one should ideally compare phylogenetically independent pairs of closely related deceptive and rewarding species. At present, there are very few estimates available of genetic differentiation among orchid populations, and they do not indicate a marked difference between deceptive and rewarding orchid species. Published estimates of population differentiation $\left(G_{\mathrm{ST}}\right.$ and $\left.F_{\mathrm{ST}}\right)$ range between 0.015 and 0.45 (median $=0.072, N=18$ ) for nonrewarding species, and between 0.045 and $0.47($ median $=0.083, N=3$ ) for rewarding orchids (Table 4).

The Mantel test indicated no correlation between geographical and genetic distance among C. bulbosa populations, if the southernmost population was excluded. No correlation between geographical and genetic distance among populations is expected if founders of new populations are drawn more or less at random from populations over a large geographical area, or if long-distance pollen dispersal is frequent.

The allele frequencies at the Tpi locus in the southernmost population sampled (Population 19) differed markedly from those in the other populations sampled (Fig. 2). As a consequence, estimates of $F_{\mathrm{ST}}$ and of the correlation between genetic and
Table 4 Estimates of population differentiation $\left(F_{\mathrm{ST}}\right.$ or $\left.G_{\mathrm{ST}}\right)$ in rewarding and deceptive orchids. To indicate the size of the geographical area covered by a given study, the distance between the two most distant populations sampled is given

\begin{tabular}{|c|c|c|c|c|}
\hline Species & $\begin{array}{c}F_{\mathrm{ST}} / \\
G_{\mathrm{ST}}\end{array}$ & $N$ & $\begin{array}{c}\text { Distance } \\
(\mathrm{km})\end{array}$ & Reference \\
\hline \multicolumn{5}{|l|}{ Rewarding } \\
\hline Gymnadenia conopsea & 0.471 & 16 & 750 & Scacchi \& de Angelis (1989) \\
\hline Leporella fimbriata & 0.045 & 4 & 30 & Peakall \& James (1989) \\
\hline Spiranthes diluvialis & 0.083 & 12 & 690 & Arft \& Ranker (1998) \\
\hline \multicolumn{5}{|l|}{ Nonrewarding } \\
\hline Caladenia tentactulata & 0.034 & 9 & 210 & Peakall \& Beattie (1996) \\
\hline Calypso bulbosa & 0.072 & 21 & 216 & Present study \\
\hline Cephalanthera longifolia & 0.104 & 3 & 10 & Scacchi et al. (1991) \\
\hline C. rubra & 0.247 & 7 & 17 & Scacchi et al. (1991) \\
\hline Cypripedium acaule & 0.164 & 4 & 500 & Case (1994) \\
\hline C. calceolus & 0.194 & 15 & 2300 & Case (1994) \\
\hline C. candidum & 0.069 & 5 & 215 & Case (1994) \\
\hline C. reginae & 0.349 & 3 & 185 & Case (1994) \\
\hline Orchis laxiflora & 0.116 & 13 & 2000 & Arduino et al. (1996) \\
\hline O. longicornu & 0.015 & 6 & 190 & Corrias et al. (1991) \\
\hline O. mascula & 0.083 & 3 & 8 & Scacchi et al. (1990) \\
\hline O. morio & 0.055 & 18 & 960 & Rossi et al. (1992) \\
\hline O. palustris & 0.448 & 8 & 2150 & Arduino et al. (1996) \\
\hline O. papilionacea & 0.038 & 4 & 20 & Scacchi et al. (1990) \\
\hline O. pauciflora & 0.040 & 3 & 12 & Scacchi et al. (1990) \\
\hline O. provincialis & 0.023 & 2 & 14 & Scacchi et al. (1990) \\
\hline O. purpurea & 0.042 & 5 & 12 & Scacchi et al. (1990) \\
\hline O. tridentata & 0.039 & 4 & 11 & Scacchi et al. (1990) \\
\hline
\end{tabular}


geographical distances were influenced strongly by the inclusion of this population in the data set. Additional sampling of populations to the south and to the east of population 19 might shed some light on whether the deviating allele frequencies reflect an origin that is different from the other populations included in the present study.

\section{Acknowledgements}

We thank E. Lundqvist and A. Höglund for advice and help in the laboratory, A. Westerbergh and K. Kärkkäinen for valuable discussions, and T. Crawford, B. Giles, $\mathrm{P}$. Ingvarsson and two anonymous reviewers for comments on the manuscript. This study was supported financially by grants from the World Wide Fund for Nature, the Swedish Council for Forestry and Agriculture Science, and from the Swedish Natural Sciences Research Council to J.A. and the Gunnar and Ruth Björkmans Fund for Botanical Research in Northern Sweden to R.A.

\section{References}

ACKerman, J. D. 1981. Pollination biology of Calypso bulbosa var. occidentalis (Orchidaceae): a food-deception system. Madroño, 3, 101-110.

ALEXANDERSSON, R. AND ÅGREN, J. 1996. Population size, pollinator visitation and fruit production in the deceptive orchid Calypso bulbosa. Oecologia, 107, 533-540.

ARDUINO, P., VERRA, F., CIANCHI, R., ROSSI, W., CORRIAS, B. AND BULLINI, L. 1996. Genetic variation and natural hybridization between Orchis laxiflora and Orchis palustris (Orchidaceae). Pl. Syst. Evol, 202, 87-109.

ARFT, A. M. AND RANKER, T. A. 1998. Allopolyploid origin and population genetics of the rare orchid Spiranthes diluvialis. Am. J. Bot., 85, 110-122.

CASE, M. A. 1994. Extensive variation in the levels of genetic diversity and degree of relatedness among five species of Cypripedium (Orchidaceae). Am. J. Bot., 81, 175-184.

CORRIAS, B., ROSSI, W., ARDUINO, P., CIANCHI, R. AND BULLINI, L. 1991. Orchis longicornu Poiret in Sardinia: genetic, morphological and chorological data. Webbia, 45, 71-101.

CRAWFORD, T. J. 1984. What is a population? In: Shorrocks, B. (ed.) Evolutionary Ecology, pp. 135-174. Blackwell Scientific Publications, Oxford.

FENSTER, C. B. 1991. Gene flow in Chamaecrista fasciculata (Leguminosae) I. Gene dispersal. Evolution, 45, 398-409.

GILES, B. E., LUNDQVIST, E. AND GOUDET, J. 1998. Restricted gene flow and subpopulation differentiation in Silene dioica. Heredity, 80, 715-723.

GOUDET, J. 1995. FSTAT Vers. 1.2. A computer program to calculate $F$-statistics. J. Hered., 86, 485-486.

GOUdET, J., DE MEEÜS, T., DAY, A. J. AND GLIDDON, C. J. 1995. The different levels of population structuring of the dogwhelk, Nucella lapillus, along the south Devon coast.
In: Beaumont, A. R. (ed.) Genetics and Evolution of Aquatic Organisms, pp. 81-95. Chapman \& Hall, London.

HAMRICK, J. L. AND GODT, M. J. 1989. Allozyme diversity in plant species. In: Brown, A. H. D., Clegg, M. T., Kahler, A. L. and Weir, B. S. (eds) Plant Population Genetics, Breeding, and Genetic Resources, pp. 43-63. Sinauer Associates, Sunderland, MA.

HUlTéN, E. AND FRIES, M. 1986. Atlas of North European Vascular Plants North of the Tropic of Cancer. I-III. Koeltz, Königstein.

JAIN, S. K. 1979. Estimation of outcrossing rates: Some alternative procedures. Crop Sci., 19, 23-26.

KIMURA, M. AND WEISS, G. H. 1964. The stepping-stone model of population structure and the decrease of genetic correlation with distance. Genetics, 49, 561-576.

LEVIN, D. A. AND KERSTER, H. W. 1974. Gene flow in seed plants. Evol. Biol., 7, 139-220.

LID, J. 1979. Norsk Og Svensk Flora. Det norske samlaget, Oslo.

MANLY, B. F. J. 1985. The Statistics of Natural Selection. Chapman \& Hall, London.

MURREN, C. J. AND ELlison, A. M. 1998. Seed dispersal characteristics of Brassovola nodosa (Orchidaceae). Am. J. Bot., 85, 675-680.

PEAKALL, R. AND BEATTIE, A. J. 1991. The genetic consequences of worker ant pollination in a self-compatible, clonal orchid. Evolution, 45, 1837-1848.

PEAKAll, R. AND BEATtie, A. J. 1996. Ecological and genetic consequences of pollination by sexual deception in the orchid Caladenia tentactulata. Evolution, 50, 2207-2220.

PEAKALl, R. AND JAMES, S. H. 1989. Outcrossing in an ant pollinated clonal orchid. Heredity, 62, 161-167.

RASMUSSEN, H. N. 1995. Terrestrial Orchids from Seed to Mycotrophic Plant. Cambridge University Press, Cambridge.

ROSSI, W., CORRIAS, B., ARDUINO, P., CIANCHI, R. AND BULLINI, L. 1992. Gene variation and gene flow in Orchis morio (Orchidaceae) from Italy. Pl. Syst. Evol., 179, 43-58.

SCACCHI, R. AND DE ANGELIS, G. 1989. Isoenzyme polymorphisms in Gymnadenia conopsea and its inferences for systematics within this species. Biochem. Syst. Ecol., 17, $25-33$.

SCACCHI, R., DE ANGELIS, G. AND CORBO, R. M. 1991. Effect of the breeding system on the genetic structure in three Cephalanthera spp. (Orchidaceae). Pl. Syst. Evol., 176, 53-61.

SCACCHI, R., DE ANGELIS, G. AND LANZARA, P. 1990. Allozyme variation among and within eleven Orchis species (fam. Orchidaceae), with special reference to hybridizing aptitude. Genetica, 81, 143-150.

SLAtKin, M. 1985. Gene flow in natural populations. Ann. Rev. Ecol. Syst., 16, 393-430.

SOltis, D. E., HAUFLER, C. H., DARROW, D. C. AND GASTONY, G. J. 1983. Starch gel electhrophoresis of ferns: a compilation of grinding buffers, gel and electrode buffers, and staining schedules. Am. Fern J., 73, 9-27.

TURNER, M. E., STEPHENS, J. C. AND ANDERSON, W. W. 1982. Homozygosity and patch structure in plant populations as 
a result of nearest-neighbor pollination. Proc. Natl. Acad. Sci. U.S.A., 79, 203-207.

WEIR, B. S. AND COCKERHAM, C. C. 1984. Estimating $F$-statistics for the analysis of population structure. Evolution, 38, 1358-1370.

WENDEL, J. F. AND WEEDEN, N. F. 1989. Visualization and interpretation of plant isozymes. In: Soltis, D. E. and Soltis,
P. S. (eds) Isozymes in Plant Biology, pp. 46-72. Chapman \& Hall, London.

WILLIAMS, C. F. AND GURIES, R. P. 1994. Genetic consequences of seed dispersal in three sympatric forest herbs. I. Hierarchial population-genetic structure. Evolution, 48, 791-805.

Wright, s. 1951. The genetical structure of populations. Ann. Eugen., 15, 323-354. 